\title{
ANALISIS PENGARUH MOTIVASI KERJA, GAYA KEPEMIMPINAN, DISIPLIN KERJA TERHADAP KINERJA KERJA KARYAWAN PT. SIANTAR TOP WARU-SIDOARJO
}

\author{
Kasino $^{1}$, \\ Fakultas Ekonomi dan Bisnis Universitas Maarif Hasyim Latif, Sidoarjo Jawa Timur \\ kasinows507@gmail.com \\ Nurrul Fitri Indrayanti ${ }^{2}$ \\ Fakultas Ekonomi dan Bisnis Universitas Maarif Hasyim Latif, Sidoarjo Jawa Timur
}

\begin{abstract}
ABSTRAK
Penelitian ini bertujuan untuk menguji dan menganalisis pengaruh motivasi kerja, gaya kepemimpinan, dan disiplin kerja terhadap kinerja karyawan PT Siantar Top Waru Sidoarjo. Pengumpulan data dilakukan melalui penyebaran kuesioner dan dilaksanakan pada 104 karyawan PT Siantar Top Waru Sidoarjo. Analisis data pada penelitian ini menggunakan bantuan SPSS versi 16. Teknik sampling yang dipakai adalah metode simple random sampling dan teknik pengujian data yang digunakan dalam penelitian ini meliputi uji validitas dengan analisis faktor, uji reliabilitas dengan Alpha Cronbach. Uji asumsi klasik dan analisis regresi liner berganda, untuk menguji dan membuktikan hipotesis penelitian. Hasil analisis menunjukkan bahwa motivasi kerja berpengaruh positif dan signifikan terhadap kinerja karyawan. Gaya kepemimpinan berpengaruh positif dan signifikan terhadap kinerja karyawan. Disiplin kerja berpengaruh positif dan signifikan terhadap kinerja karyawan dan Disiplin kerja memiliki pengaruh yang paling dominan terhadap kinerja kerja karyawan.
\end{abstract}

Kata Kunci: Motivasi kerja, Gaya kepemimpinan, Disiplin Kerja dan Kinerja Karyawan.

\section{PENDAHULUAN}

Pada era Globalisasi sekarang ini organisasi dituntut untuk memiliki kemampuan dalam berbagai macam aspek dan untuk merumuskan strategi dalam menghadapi perubahan yang terjadi di organisasi dalam mencapai tujuan bersama. Tercapainya tujuan organisasi tersebut tergantung pada bagaimana organisasi dan karyawan dapat mengembangkan kemampuan baik dibidang manejerial, hubungan antar manusia maupun di bidang teknis operasional.

Perusahaan dalam meningkatkan usahanya, tidak dapat melepaskan perhatiannya terhadap unsur sumber daya manusia sebagai salah satu dari faktor-faktor produksi dan sebagai aset perusahaan. Faktor manusia merupakan hal yang sangat penting, karena berhasil tidaknya suatu 
perusahaan tergantung pada kualitas dari karyawannya itu sendiri. Oleh sebab itu, sumber daya manusia perlu mendapatkan perhatian utama karena mempunyai peranan yang sangat penting terhadap seluruh kegiatan perusahaan.

Pengembangan SDM merupakan cara organisasi agar dapat mempertahankan eksistensi kerja semua komponen organisasi. Sebuah organisasi harus mampu mengoptimalkan kemampuan sumber daya manusia yang dimilikinya agar pencapaian sasaran dapat terlaksana, namun hal tersebut tidaklah sederhana perlu pemahaman yang baik tentang organisasi, perlu ada strategi

pengembangan yang matang agar SDM yang dimiliki sebuah organisasi terpakai sesuai kebutuhan.

Visi dan misi suatu perusahaan dapat tercapai apabila perusahaan mampu meningkatkan kinerja karyawan di perusahaan tersebut. Kinerja merupakan hasil kerja yang mampu diperoleh pekerja, sebuah proses manajemen atau suatu organisasi secara keseluruhan, dimana hasil kerja tersebut dapat ditunjukan buktinya secara nyata baik dari segi kualitas maupun kuantitas. Baik buruk hasil kerja karyawan dapat dilihat dari standar kinerja yang telah ditetapkan perusahaan. Jika karyawan memberikan hasil kerja sesuai standar kinerja yang telah ditetapkan, maka kinerja karyawan tergolong baik.

Kinerja karyawan yang tinggi sangatlah diharapkan oleh perusahaan terserbut. Semakin banyak karyawan yang mempunyai kinerja tinggi, maka produktivitas perusahaan secara keseluruhan akan meningkat sehingga perusahaan akan dapat bertahan dalam persaingan global. Karyawan dituntut untuk mampu menyelesaikan tugas dan tanggung jawabnya secara efektif dan efisien. Keberhasilan karyawan dapat diukur melalui kepuasan konsumen, berkurangnya jumlah keluhan dan tercapainya target yang optimal.

Berdasarkan survei, peneliti menemukan adanya kekurangan menaati tata tertib, ketentuanketentuan perusahaan yang memberatkan karyawan, disamping gaya kepemimpinan dan motivasi kerja yang cukup tinggi. Kemudian timbul pemikiran bagaimana keseluruhan faktor tersebut saling berkesinambungan sehingga mempengaruhi kinerja karyawan.

\section{Rumusan Masalah}

Manusia merupakan sumber daya yang paling menentukan dalam mencapai tujuan yang diinginkan perusahaan. Permasalahan dari perusahaan ini adalah tinggi rendahnya kinerja karyawan, untuk suatu upaya yang dapat meningkatkan kinerja karyawan, dengan permasalahan 
tersebut diduga faktor gaya kepemimpinan, motivasi kerja dan disiplin kerja kerja mempunyai pengaruh terhadap kinerja karyawan. Berdasarkan permasalahan tersebut maka dirumuskan permasalahan sebagai berikut:

1. Apakah motivasi kerja berpengaruh signifikan terhadap kinerja kerja karyawan di PT. Siantar Top Waru-Sidoarjo ?

2. Apakah gaya kepemimpinan berpengaruh signifikan terhadap kinerja kerja karyawan di PT. Siantar Top Waru-Sidoarjo ?

3. Apakah disiplin kerja berpengaruh signifikan terhadap kinerja kerja karyawan di PT. Siantar Top Waru-Sidoarjo ?

4. Manakah diantara variabel motivasi kerja, gaya kepemimpinan, disiplin kerja yang secara signifikan mempunyai pengaruh dominan terhadap kinerja kerja karyawan bagian produksi produksi PT. Siantar Top Waru-Sidoarjo ?

\section{TINJAUAN PUSTAKA}

\section{Motivasi kerja}

Menurut (Malayu Hasibun, 2012:141) motivasi kerja adalah suatu pemberian daya penggerak yang menciptakan kegairahan kerja seseorang agar mereka mau bekerja sama, bekerja efektif dan terintegrasi dengan segala daya upayanya untuk mencapai kepuasan.

Motivasi kerja adalah sebuah alasan atau dorongan untuk bertindak. Orang yang tidak mau bertindak sering kali disebut tidak memiliki motivasi kerja. Alasan atau dorongan itu bias datang dari luar maupun dari dalam diri sendiri. Sebenarnya dasar semua motivasi kerja itu dating dari dalam diri, faktor luar hanyalah pemicu munculnya motivasi kerja tersebut. Motivasi kerja dari luar adalah motivasi kerja yang pemicuna datang dari luar diri kita. Sementar motivasi kerja dari dalam adalah motivasi kerja yang muncul dari inisiatif diri kita. Pada dasarnya motivasi kerja ada dua yaitu meraih kenikmatan atau menghindari dari rasa kesulitan.

Motivasi kerja sangat diperlukan bagi karyawan dikarenakan dapat mendorong karyawan bekerja dengan baik yang sesuai dengan beban-beban pekerjaan yang telah dibebankan kepada karyawan. Memotivasi kerja dalam suatu pekerjaan adalah salah satu tugas dari atasan atau pimpinan agar bawahanya dapat bekerja sesuai dengan mengarahkan yang diberikanya.

Perusahaan bukan saja mengharapkan karyawan mampu, cakap, dan terampil, tetapi yang terpenting mereka mau bekerja giat dan berkeinginan untuk mencapai hasil kerja yang maksimal. 
Kemampuan dan kecakapan karyawann tidak ada artinya bagi perusahaan jika mereka tidak mau bekerja giat.

\section{Gaya Kepemimpinan}

Menurut (Malayu Hasibun, 2012:170) kepemimpinan adalah cara seseorang pemimpin mempengaruhi perilaku bawahanya, agar mau bekerja sama dan bekerja secara produktif untuk pmencapai tujuan organisasi.

Menurut (Stephen P. Robbins, 2007:49) kepemimpinan adalah suatu kemampuan untuk mempengaruhi sebuah kelompok untuk mencapai suatu visi atau serangkaian tujuan tertentu.

Menurut (Saydam Gouzali, 2000:702) kepemimpinan adalah kemampuan lebih yang dimiliki oleh seseorang (baik dalam organisasi atau tidak) untuk mepengaruhi orang-orang yang ada dalam lingkungannya, agar mereka bersedia bekerja untuk mencapai tujuan yang diingkan pemimpin

Kepemimpinan (leadership) yang ditetapkan oleh manjer dalam organisasi dapat menciptakan integrasi yang serasi dan mendorong gairah kerja karyawan untuk mencapai sasaran yang maksimal. Pelaksanaan kepemimpinan cenderung menumbuhkan kepercayaan, loyalias, dan internal motivasi kerja para bawahanya dengan cara persuasif. Hal ini akan diperoleh karena kecakapan, kemampuan dan perilakunya.

Kedudukan kepemimpinan dalam suatu organisasi atau perusahaan amat penting, dalam usaha mencapai tujuan organisasi atau perusahaan itu. Berhasil atau gagalnya suatu perusahaan dalam mengembangkan misinya untuk mencapai tujuan, sebagian besar ditentukan oleh mutu kepemimpinan yang dimaikan oleh orang yang diserahi tugas-tugas kepemimpinan dalam organisasi.

Gaya kepemimpinan pada dasarnya mengandung pengertian sebagai salah satu perwujudan tingkah laku dari seseorang pemimpin yang menyangkut kemampuan dalam memimpin.

\section{Disiplin kerja}

Menurut (Tani Handoko, 2012:208) disiplin kerja adalah suatu kegiatan manajemen untuk menjalankan standar-standar organisasional. Disiplin kerja yang baik mencerminkan besarnya rasa tanggung jawab sesorang terhadap tugas-tugas yang diberikan.

Menurut (Malayu Hasibun, 2012:193) Kedisiplin kerjaan adalah fungsi operatif keenam dari manajemen sumber daya manusia. Kedisiplin kerjaan merupakan fungsi operatif MSDM yang terpenting karena semakin baik disipin karyawan semakin tinggi prestasi kerja yag dapat dicapai. 
Tanpa disiplin kerja karyawan yang baik, sulit bagi organisasi perusahaan mencapai hasil yang optimal.

Kedisiplin kerjaan adalah kesadaran dan kesediaan seseorang menaati semua peraturan perusahaan dan norma-norma sosial yang berlaku. Kesadaran adalah suatu sikap seseorang yang secara sukarela menaati semua peraturan dan sadar akan tugas dan tanggung jawabnya. Kesediaan adalah suatu sikap, tingkah laku dan perbuatan sesorang yang sesuai dengan peraturan perusahaan, baik yang tertulis maupun tidak.

Maka sesorang akan bersedia mematuhi semua peraturan serta melaksanakan tugastugasnya, baik secara sukarela maupun karena terpaksa. Kedisiplin kerjaan diartikan apabila karyawan selalu datang dan pulang tepat pada waktunya, mengerjakan semua pekerjaana dengan baik, mematuhi semua peraturan perusahaan dan norma-norma social yang berlaku.

Peraturan sangat diperlukan untuk memberikan bimbingan dan penyuluhan bagi karyawan dalam menciptakan tata tertib yang baik diperusahaan. Dengan tata tertib yang baik, semangat kerja, moral kerja, efesiensi, dan fektivitas kerja karyawan akan meningkat. Hal ini akan mendukung tercapainya tujuan perusahaan karyawan.

\section{Kinerja Kerja Karyawan}

Kinerja berasal dari pengertian performance. Ada pula yang memberikan pengertian performance sebagai hasil kerja atau prestasi kerja. Namun sebenarnya kinerja kerja karyawan mempunyai makna yang lebih luas, bukan hanya hasil kerja tetapi termasuk bagaimana proses pekerjaan berlangsung.

Kinerja kerja karyawan adalah fungsi hasil-hasil pekerjaan /kegiatan yang ada dalam perusahaan yang dipengaruhi faktor - faktor intern dan ekstern organisasi dalam mencapai tujuan yang ditetapkan selama periode waktu tertentu (menurut Moh.Pabundu,2012: 121).

Proses komunikasi yang dilakukan secara terus menerus dalam kemitraann antara karyawan dengan atasan langsungnya dapat disebut manajemen Kinerja kerja karyawan. Proses komunikasi ini meliputi kegiatan membangun harapan yang jelas serta pemahaman mengenai pekerjaan yang akan dilakuka. Proses komunikasi merupakan system, memiliki sejumlah bagian yang semuanya di ikut sertakan, apabila manajemen Kinerja kerja karyawan ini hendaknya memberikan nilai tambah bagi organisasi, manajer dan karyawan. 
Maka pada dasarnya manajemen Kinerja kerja karyawan merupakan gaya manajemen dalam mengelola sumber daya yang berorientasi pada Kinerja kerja karyawan yang melakukan proses komunikasi secara terbuka dan berkelanjutan dengan menciptakan visi bersama dan pendekatan strategis serta terpadu sebagai kekuatan pendorong untuk mencapai tujuan organisasi atau perusahaan.

Fungsi pekerjaan atau kegiatan adalah pelaksanaan hasil pekerjaan atau kegiatan sesorang atau kelompok yang menjadi wewenang dan tanggung jawabnya dalam suatu organisasi. Sedangkan factor-faktor yang berpengaruh terhadap hasil pekerjaan prestasi kerja seseorang atau kelompok terdiri dari factor intern dan ekstern.

\section{Hasil dan Pembahasan}

dalam penelitian ini diuji kebenarannya dengan menggunakan uji parsial. Pengujian dilakukan dengan melihat taraf signifikansi (pvalue), jika taraf signifikansi yang dihasilkan dari perhitungan di bawah 0,05 maka hipotesis diterima, sebaliknya jika taraf signifikansi hasil hitung lebih besar dari 0,05 maka hipotesis ditolak.

Tabel

\section{Hasil Uji t Secara Parsial}

\begin{tabular}{|c|c|c|c|}
\hline \multicolumn{4}{|c|}{ Coefficients $^{\mathrm{a}}$} \\
\hline \multicolumn{2}{|c|}{ Model } & \multirow{2}{*}{$\frac{T}{-2.185}$} & \multirow{2}{*}{\begin{tabular}{|c} 
Sig. \\
.031
\end{tabular}} \\
\hline 1 & (Constant) & & \\
\hline & MK & 6.132 & .000 \\
\hline & GK & 3.300 & .001 \\
\hline & DK & 6.877 & .000 \\
\hline
\end{tabular}

a. Dependent Variable: KK

Sumber: Lampiran output SPSS

\section{Uji F (Uji Hipotesis Secara Simultan)}

Untuk menguji pengaruh variabel bebas secara bersama-sama diuji dengan menggunakan uji F. Hasil perhitungan regresi secara simultan diperoleh sebagai berikut: 
Tabel

Hasil uji F secara simultan

\begin{tabular}{|ll|ll|l|l|l|l|}
\hline \multicolumn{2}{|l|}{ ANOVA $^{\mathbf{b}}$} & \multicolumn{5}{|l|}{ Sum } \\
\hline \multicolumn{2}{|l|}{ Model } & Squares & df & Mean Square & F & Sig. \\
\hline 1 & Regression & 18.827 & 3 & 6.276 & 66.622 & $.000^{\text {a }}$ \\
& Residual & 9.420 & 100 & .094 & & \\
& Total & 28.247 & 103 & & & \\
\hline
\end{tabular}

a. Predictors: (Constant), DK, MK, GK

b. Dependent Variable: KK

Sumber: Lampiran output SPSS

\section{Pengaruh Motivasi kerja terhadap Kinerja Karyawan}

Hasil pengujian hipotesis (H1) telah membuktikan terdapat pengaruh antara motivasi kerja terhadap kinerja karyawan. Melalui hasil perhitungan yang telah dilakukan diperoleh nilai t hitung sebesar 6,132 dengan taraf signifikansi hasil sebesar 0,000 tersebut lebih kecil dari 0,05, yang berarti bahwa hipotesis dalam penelitian ini menerima Ha dan menolak Ho. Pengujian ini secara statistik membuktikan bahwa motivasi kerja berpengaruh positif dan signifikan terhadap kinerja karyawan. Artinya bahwa ada pengaruh antara variabel motivasi terhadap kinerja karyawan di PT Siantar Top Waru-Sidoarjo. Hasil ini mendukung penelitian sebelumnya oleh (sartono, 2008) yang menyatakan bahwa ada pengaruh positif dan signifikan antara motivasi kerja terhadap kinerja karyawan.

\section{Pengaruh Gaya Kepemimpinan terhadap Kinerja Karyawan}

Hasil pengujian hipotesis $(\mathrm{H} 2)$ telah membuktikan terdapat pengaruh antara gaya kepemimpinan terhadap kinerja karyawan. Melalui hasil perhitungan yang telah dilakukan diperoleh nilai t hitung sebesar 3,300 dengan taraf signifikansi hasil sebesar 0,001 tersebut lebih kecil dari 0,05, dengan demikian Ha diterima dan Ho ditolak. Pengujian ini secara statistik membuktikan bahwa gaya kepemimpinan berpengaruh positif dan signifikan terhadap kinerja karyawan. Artinya bahwa ada pengaruh antara variabel gaya kepemimpinan terhadap kinerja 
karyawan di PT. Siantar Top Waru-Sidoarjo Waru-Sidoarjo Hasil ini mendukung penelitian sebelumnya oleh (Fahmi, 2009) yang menguji pengaruh gaya kepemimpinan terhadap kinerja karyawan dengan hasil analisis yaitu gaya kepemimpinan mempunyai pengaruh positif dan signifikan terhadap kinerja karyawan.

\section{Pengaruh Disiplin Kerja terhadap Kinerja Karyawan}

Hasil pengujian hipotesis (H3) telah membuktikan terdapat pengaruh antara disiplin kerja terhadap kinerja karyawan. Melalui hasil perhitungan yang telah dilakukan didapat nilai t hitung sebesar 6,877 dengan taraf signifikansi hitung sebesar 0,000 tersebut lebih kecil dari 0,05, yang berarti bahwa hipotesis dalam penelitian ini menolak Ho dan menerima Ha, Pengujian ini secara statistik membuktikan bahwa disiplin kerja berpengaruh positif dan signifikan terhadap kinerja karyawan. Artinya bahwa ada pengaruh antara variabel disiplin kerja terhadap kinerja karyawan di PT. Siantar Top Waru-Sidoarjo Waru-Sidoarjo

\section{Pengaruh yang paling dominan terhadap kinerja kerja karyawan}

Berdasarkan nilai standardized coefficient beta disebutkan bahwa standardized coefficient beta untuk variabel disiplin kerja adalah sebesar 0,450. nilai standardized coefficient beta untuk variabel gaya kepemimpinan adalah sebesar 0,229 dan motivasi kerja adalah 0,389 . Hal ini menunjukkan bahwa nilai standardized coefficient beta terbesar ada pada variabel disiplin kerja. Dengan demikian variabel bebas yang berpengaruh dominan terhadap kinerja karyawan adalah variabel disiplin kerja.

Dari hasil penelitian diatas dapat disimpulkan bahwa variabel yang mempunyai pengaruh yang dominan adalah disiplin kerja yang memiliki nilai standardized coefficient beta paling besar. Hal ini mengindentifikasi bahwa jika perusahaan ingin meningkatkan kinerja karyawan, dapat dilakukan dengan cara memberikan motivasi-motivasi terhadap karyawan dapat berupa dengan memberikan penghargaan, keamanan kerja dan kerja sama (sosial) sehingga karyawan tersebut dapat termotivasi untuk bekerja lebih baik. Sehingga dapat meningkatkan kinerja di dalam perusahaan. 


\section{Kesimpulan}

Dari data primer yang diperoleh dari penyebaran kuesioner maka dilakukan pengujian reliabilitas untuk mengetahui bahwa jawaban responden terhadap pernyataan konsisten dari waktu ke waktu. Dan dilakukan pengujian validitas untuk mengukur sah tidaknya suatu kuesioner. Hasil dari uji reliabilitas dan validitas menunjukkan bahwa seluruh pernyataan dalam setiap variabel reliabel dan valid. Dalam uji asumsi klasik yang meliputi uji multikolonieritas, uji heteroskedastisitas menunjukkan bahwa dalam model regresi tidak ditemukan adanya korelasi antar variabel bebas dan tidak terjadi heteroskedastisitas. Dari pembahasan yang telah diuraikan, maka dapat ditarik kesimpulan sebagai berikut:

1. Hasil pengujian hipotesis telah membuktikan terdapat pengaruh antara motivasi kerja dengan kinerja karyawan. Pengujian membuktikan bahwa motivasi memiliki pengaruh positif dan signifikan terhadap kinerja karyawan. Dilihat dari perhitungan yang telah dilakukan diperoleh nilai koefisien sebesar 0,455 dan nilai t hitung sebesar 6,132 dengan taraf signifikansi hasil sebesar 0,000 tersebut lebih kecil dari 0,05, yang berarti bahwa hipotesis dalam penelitian ini menerima Ha dan menolak Ho. Hal ini mendukung penelitian yang dilakukan oleh penelitian (Sartono,2008) mengemukakan bahwa salah satu faktor yang mempengaruhi kinerja adalah motivasi kerja.

2. Hasil pengujian hipotesis telah membuktikan terdapat pengaruh antara gaya kepemimpinan dengan kinerja karyawan. Pengujian membuktikan bahwa gaya kepemimpinan memiliki pengaruh positif dan signifikan terhadap kinerja karyawan. Dilihat dari perhitungan yang telah dilakukan diperoleh nilai koefisien sebesar dan nilai t hitung sebesar 3,300 dengan nilai signifikansi sebesar 0,001 tersebut lebih kecil dari 0,05 dengan demikian Ha diterima dan Ho ditolak. Hal ini mendukung penelitian yang dilakukan oleh penelitian menurut Fahmi (2009) bahwa gaya kepemimpinan pada dasarnya menekankan untuk menghargai tujuan individu sehingga nantinya para individu akan memiliki keyakinan bahwa kinerja aktual akan melampaui harapan kinerja mereka.

3. Hasil pengujian hipotesis telah membuktikan terdapat pengaruh antara disiplin kerja dengan kinerja karyawan. Pengujian membuktikan bahwa disiplin kerja memiliki pengaruh positif terhadap kinerja karyawan. Dilihat dari perhitungan yang telah dilakukan diperoleh nilai dan nilai t hitung 6,877 dengan taraf signifikansi hitung sebesar 0,000 tersebut lebih kecil dari 0,05, 
yang berarti bahwa hipotesis dalam penelitian ini menolak Ho dan menerima Ha. Hal ini mengungkapkan bahwa disiplin kerja karyawan bagian dari faktor kinerja kerja.

4. Disiplin kerja memiliki pengaruh yang paling dominan terhadap kinerja kerja karyawan. Dalam pengujian membuktikan bahwa nilai standardized coefficient beta disebutkan bahwa untuk variabel disiplin kerja sebesar 0,450 yaiyu nilai terbesar dari standardized coefficient beta

\section{Saran}

Berdasarkan kesimpulan yang telah dilakukan maka saran yang dapat diberikan dalam penelitian ini yaitu:

1. Bagi Perusahaan

a. Hendaknya perusahaan dalam meningkatkan kinerja karyawan lebih menitik beratkan pada gaya kepemimpinan, dilihat dari kuesioner yang telah diisi oleh karyawan PT Siantar Top Waru Sidoarjo tersebut diperoleh data bahwa karyawan memiliki gaya kepemimpinan yang rendah pada pekerjaan yang mereka laksanakan, sehingga dengan perusahaan lebih memperhatikan gaya kepemimpinan pada karyawannya misalnya gaya kepemimpinan partisipatif dimana kepemimpinan ini dilakukan untuk menciptakan kerja sama, menumbuhkan loyalitas dan partisipasi para bawahanya sehingga dapat mendorong para karyawan akan termotivasi kerja, dengan demikian pimpinan akan selalu membina bawahanya untuk menerima tanggung jawab atas pekerjaanya dan kinerja akan meningkat.

b. Untuk motivasi kerja pada karyawan PT Siantar Top Waru Sidoarjo lebih ditingkatkan kembali agar para karyawan lebih terdorong dalam bekerja dan bertanggung jawab lebih besar atas pekerjaanya, misalnya perusahaan dapt memmberikan keamanan dalam bekerja, memberikan penghargaan kepada karyawan yang berprestasi. Dengan demikian kinerja karyawan akan meningkat.

c. Untuk disiplin kerja tetap di PT Siantar Top Waru Sidoarjo sangat bagus dan tetap dipertahankan karena dari kuesioner yang telah diisi oleh karyawan PT Siantar Top Waru Sidoarjo tersebut diperoleh data bahwa karyawan memiliki disiplin kerja yang tinggi pada pekerjaan yang mereka laksanakan. 


\section{DAFTAR PUSTAKA}

Fahmi. 2009. Jurnal Analisis Pengaruh Gaya Kepemimpinan dan Motivasi Kerja Terhadap Kinerja Karyawan Pegawai SPBU Pandanaran Semarang. Penelitian. Universitas Gunadarma. Jakarta

Gouzali, Saydam. 2000. Manajemen Sumber Daya Manusia. IKAPI. Jakarta

Handoko, Tani. 2012. Manajemen Personalia dan Sumber Daya Manusia. BPFE. Yogyakarta

Hasibun, Malayu. 2012. Manajemen Sumber Daya Manusia. Bumi Aksara. Jakarta

Husnan, Heidjrachman Suad. 1994. Manajemen Personalia. BPFE. Jakarta

Robbins, Stephen P. 2008. Perilaku Organisasi“Organizational Behaviour”. Buku 1.SalembaEmpat. Jakarta

Sapullete, Ludy. 2011. Jurnal Pengaruh Komitmen Organisasional, Kepuasan Kerja dan Loyalitas Pegawai Terhadap Kinerja Karyawan Pegawai PT. PLN Maluku Utara. Penelitian. Politeknik Negeri Ambon

Sartono. 2008. Jurnal Kepemimpinan, Profesional, Motivasi Kerja, Lingkungan Kerja dan Disiplin Kerja Terhadap Kinerja Karyawan Organisasi pada Universitas Sebelas Maret Surakarta. Penelitian. STIE AUB Surakarta

Sugiyono. 2013. Statisika Untuk Penelitian. IKAPI. Alfabeta Bandung

Sujianto, Agus Eko. 2009. Aplikasi Statistil dengan SPSS 16.0. Prestasi Pustakarya. Jakarta 